\title{
Complement Component C3 Plays a Critical Role in Protecting the Aging Retina in a Murine Model of Age-Related Macular Degeneration
}

\author{
Jaimie Hoh Kam, ${ }^{*}$ Eva Lenassi, ${ }^{* \dagger}$ Talat H. Malik, ${ }^{\ddagger}$ Matthew C. Pickering, ${ }^{\ddagger}$ and Glen Jeffery ${ }^{\star}$
}

From the Institute of Ophthalmology, * University College London, London, United Kingdom; The Eye Hospital, ${ }^{\dagger}$ Medical Centre, Ljubljana, Slovenia; and the Centre for Complement and Inflammation Research, ${ }^{\ddagger}$ Imperial College London, London, United Kingdom

Accepted for publication

April 5, 2013.

Address correspondence to Glen Jeffery, Ph.D., Institute of Ophthalmology, University College London, 11-43 Bath St, London EC1V 9EL, United Kingdom. E-mail: g.jeffery@ ucl.ac.uk.

\begin{abstract}
Complement component C 3 is the central complement component and a key inflammatory protein activated in age-related macular degeneration (AMD). AMD is associated with genetic variation in complement proteins that results in enhanced activation of $\mathrm{C} 3$ through the complement alternative pathway. These include complement factor $\mathrm{H}$ (CFH), a negative regulator of $\mathrm{C} 3$ activation. Both $\mathrm{C} 3$ inhibition and/or CFH augmentation are potential therapeutic strategies in AMD. Herein, we examined retinal integrity in aged (12 months) mice deficient in both factors $\mathrm{H}$ and $\mathrm{C} 3\left(\mathrm{CFH}^{-/-} . \mathrm{C3}^{-/-}\right), \mathrm{CFH}$ alone $\left(\mathrm{CFH}^{-/-}\right)$, or C3 alone $\left(\mathrm{C}^{-/-}\right)$, and wild-type mice $(\mathrm{C} 57 \mathrm{BL} / 6)$. Retinal function was assessed by electroretinography, and retinal morphological features were analyzed at light and electron microscope levels. Retinas were also stained for amyloid $\beta(A \beta)$ deposition, inflammation, and macrophage accumulation. Contrary to expectation, electroretinograms of $\mathrm{CFH}^{-/-} . \mathrm{C3}^{-/-}$mice displayed more severely reduced responses than those of other mice. All mutant strains showed significant photoreceptor loss and thickening of Bruch's membrane compared with wild-type $\mathrm{C} 57 \mathrm{BL} / 6$, but these changes were greater in $\mathrm{CFH}^{-1-} . \mathrm{C3}^{-/-}$ mice. $\mathrm{CFH}^{-1-} . \mathrm{C}^{-/-}$mice had significantly more $\mathrm{A} \beta$ on Bruch's membrane, fewer macrophages, and high levels of retinal inflammation than the other groups. Our data show that both uncontrolled $\mathrm{C} 3$ activation $\left(\mathrm{CFH}^{-1-}\right)$ and complete absence of $\mathrm{C3}\left(\mathrm{CFH}^{-/-} . \mathrm{C3}^{-/-}\right.$and $\left.\mathrm{C3}^{-/-}\right)$negatively affect aged retinas. These findings suggest that strategies that inhibit C3 in AMD may be deleterious. (Am J Pathol 2013, 183: 480-492; http://dx.doi.org/10.1016/j.ajpath.2013.04.008)
\end{abstract}

The complement system is a major noncellular component of the innate immunity and is important for cellular integrity, tissue homeostasis, and modification of the adaptive immune response. ${ }^{1,2}$ It is activated by three pathways: the classic, mannose-binding lectin, and alternative pathways. The central complement component $\mathrm{C} 3$ is the point of convergence of the three complement pathways ${ }^{3}$ and, thus, plays a critical role in biological processes mediated by complement activation. Its activation results in the cleavage of C3 by $\mathrm{C} 3$ convertase to smaller proinflammatory molecules, $\mathrm{C} 3 \mathrm{a}$ and $\mathrm{C} 3 \mathrm{~b}$. $\mathrm{C} 3 \mathrm{a}$ aids in the recruitment and activation of innate immune effector cells and has antimicrobial and antifungal activity. ${ }^{4} \mathrm{C} 3 \mathrm{~b}$ is an opsonin and will, through a feedback loop, amplify and trigger activation of the complement terminal pathway. ${ }^{5} \mathrm{C} 3$ deficiency is associated with an increased risk of infection. 6
Age-related macular degeneration (AMD) is the leading cause of blindness in elderly individuals in the Western world. ${ }^{8-10}$ The immune mechanism and cellular interactions in AMD are similar to those seen in other ocular diseases characterized by the accumulation of extracellular deposits, such as atherosclerosis and Alzheimer disease (AD). ${ }^{11}$ Recent studies suggest that AMD is associated with chronic inflammatory processes, ${ }^{1-14}$ and complement has been demonstrated in subretinal regions that are focal points for the disease. ${ }^{15,16}$ Furthermore, genome-wide association studies have identified polymorphisms in the factor $\mathrm{H}$ gene as major risk factors for AMD. ${ }^{17-20}$ Meanwhile, additional polymorphisms and deletions that mostly affect the alternative pathway, including C3 and factor $B,{ }^{16,21-23}$ have been revealed, suggesting that

Supported by The Rosetrees Trust. 
disruption of the delicate balance between complement activation and regulation in the subretinal tissue may contribute to AMD progression.

Given the increasing prevalence of AMD in an ageing population and the strong association between AMD and complement, it is not surprising that interest in complementtargeted drug development is being directed toward AMD. Complement inhibitors are among the few promising options for treating early AMD and potentially preventing vision loss. ${ }^{24}$ Because C3 is pivotal in all complement activation pathways, potential therapeutic targets that inhibit it are of critical interest.

To address the role of $\mathrm{C} 3$ in retinal health, we compared the aged $\mathrm{CFH}^{-1-}$ AMD mouse model with mice deficient in C3 alone, mice with combined deficiency of complement factor $\mathrm{H}(\mathrm{CFH})$ and $\mathrm{C} 3$, and wild-type (WT) mice. Our results show that the complete absence of $\mathrm{C} 3$ was deleterious to retinal health.

\section{Materials and Methods}

\section{Animals}

All animals used were subject to local and national ethical approval and guidance (University College London Ethical Committee and UK Home Office Regulations for Animal Use). Twelve-month-old $\mathrm{CFH}^{-/-}, \mathrm{C3}^{-/-}, \mathrm{CFH}^{-/-} . \mathrm{C}^{-/-}$ ( $n=8$ for each group; all backcrossed onto the C57BL/6 genetic background for $>10$ generations), and age-matched WT C57BL/6 mice $(n=8)$ were housed and maintained under standard laboratory conditions with a 12-hour day (160-lux)-night cycle. Before the experiment, all animals appeared healthy. The mice were genotyped to confirm that they are homozygous knockouts, and the retinas were subsequently tested for both complement C3 and complement factor $\mathrm{H}$ expression using immunohistochemistry (IHC). They were also tested for the $R d 8$ mutation, ${ }^{25}$ and the results were negative (data not shown). Multiple in vitro experiments were performed on each animal to provide comprehensive images of the impact of complement and ageing in terms of both retinal structure and function.

\section{Genotyping}

DNA was extracted from kidney and eyes embedded in optimal cutting temperature compound by incubating the sample at $50^{\circ} \mathrm{C}$ in lysis buffer $[100 \mathrm{mmol} / \mathrm{L}$ Tris- $\mathrm{HCl}(\mathrm{pH}$ 8.5), $5 \mathrm{mmol} / \mathrm{L}$ EDTA, 0.2\% SDS, $200 \mathrm{mmol} / \mathrm{L} \mathrm{NaCl}$, and $100 \mu \mathrm{g} / \mathrm{mL}$ proteinase $\mathrm{K}$ ] overnight.

C3 and FH genotyping was performed by PCR using Biotaq (Bioline Reagents Ltd, London, UK) with $2 \mu \mathrm{L}$ of the lysed DNA. C3 primers were as follows: WT, 5'-ACCCAGCTCTGTGGGAAGTG-3' (forward) and 5'-CTTCATAGACTGCTGCAACCA-3' (reverse); and Neo, 5'-AAGGGACTGGCTGCTATTGG-3' (forward). This yielded a WT band of $920 \mathrm{bp}$ and a recombinant band of $1100 \mathrm{bp}$. PCR conditions were initial denaturation at $95^{\circ} \mathrm{C}$ for 3 minutes, followed by 30 cycles of $94^{\circ} \mathrm{C}$ for 1 minute, $60^{\circ} \mathrm{C}$ for 1 minute, and $72^{\circ} \mathrm{C}$ for 2 minutes, followed by $72^{\circ} \mathrm{C}$ for 10 minutes. $\mathrm{FH}$ primers used were as follows: WT, $5^{\prime}$-GTAAAGGTCCTCCTCCAAGAG$3^{\prime}$ (forward) and 5'-GGTATAAACAACCTTTGCACC-3' (reverse); and Neo, 5'-GGGGATCGGCAATAAAAAGAC-3' (reverse). This yielded a WT band of $600 \mathrm{bp}$ and a recombinant band of $400 \mathrm{bp}$. PCR conditions were as follows: initial denaturation at $95^{\circ} \mathrm{C}$ for 3 minutes, followed by 30 cycles of $95^{\circ} \mathrm{C}$ for 1 minute, $55^{\circ} \mathrm{C}$ for 1 minute, and $72^{\circ} \mathrm{C}$ for 1 minute, followed by $72^{\circ} \mathrm{C}$ for 10 minutes.

To confirm whether their genotype and whether the mutant strains express the complement protein that has been knocked out, their retinas were immunostained, as described later, with a goat polyclonal anti-human factor $H$ (1:1000; Calbiochem; Millipore, Watford, UK) and a fluorescein isothiocyanate-conjugated goat anti-mouse complement component C3 (1:100; Cappel; MP Biomedicals, Cambridge, UK) to test the expression of these two proteins in the four groups of mice.

\section{ERG Data}

Electroretinography (ERG) was used to assess retinal function in response to full-field flash stimuli under scotopic and photopic conditions. Mice were dark-adapted overnight for scotopic measurements and anesthetized with $6 \%$ ketamine (National Veterinary Services Ltd, Stoke-on-Trent, UK), $10 \%$ Dormitor (National Veterinary Services Ltd), and $84 \%$ sterile water at $5 \mu \mathrm{L} / \mathrm{g}$ i.p. injections. Pupils were dilated with $1 \%$ tropicamide (MINIMS; Bausch \& Lomb, Montpellier, France). Mice were exposed to flash stimuli (duration, $10 \mu$ s to 1 millisecond; repetition rate, 0.1 to 1 $\mathrm{Hz}$; log intensity, -6.1 to $2.7 \log$ candela $(\mathrm{cd}) / \mathrm{m}^{2} ;-6.1=$ $1,-5.1=2,-4.1=3,-3.1=4,-2.1=5,-1.1=6$, $0.1=7,0.9=8,1.9=9$, and $2.7=10)$. They were then adapted to a $20-\mathrm{cd} / \mathrm{m}^{2}$ background for 20 minutes, after which photopic responses to flash stimuli (log intensity, $0 \log \mathrm{cd} / \mathrm{m}^{2}=1,1=2,1.5=3,1.7=4$, and $\left.2=5\right)$ and flicker (up to $40 \mathrm{~Hz}$ ) were assessed.

\section{IHC Data}

Mice were culled by cervical dislocation under anesthesia. The eyes from all four groups of mice were divided into different experiments. For immunostaining, the enucleated eyes ( $n=4$ from each group) were fixed in $4 \%$ para-

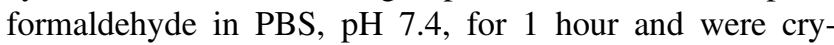
opreserved in $30 \%$ sucrose in PBS and embedded in OCT compound (Agar Scientific Ltd, Stansted, Essex, UK). Cryosections (10 $\mu \mathrm{m}$ thick) were thaw mounted on a slide and incubated for 1 hour at room temperature in 5\% normal donkey serum in $0.3 \%$ (v/v) Triton X-100 in PBS, pH 7.4, followed by an overnight incubation with the following primary antibodies: mouse monoclonal antibody to A $\beta 4 \mathrm{G} 8$ (1:500; Covance; Cambridge BioScience, Cambridge, UK), 
rabbit polyclonal to tumor necrosis factor (TNF)- $\alpha$ (1:1000; Abcam, Cambridge, UK), and calcitonin (1:100; Abcam) made in $1 \%$ normal donkey serum in $0.3 \%$ Triton X-100 in PBS. After primary antibody incubation, sections were washed several times in $0.1 \mathrm{~mol} / \mathrm{L}$ PBS and incubated in a secondary antibody conjugated with Alexa Fluor 568 (Invitrogen, Paisley, UK) made up in $2 \%$ normal donkey serum in $0.3 \%$ Triton X-100 in PBS at a dilution of 1:2000 for 1 hour at room temperature. Negative controls were undertaken by omitting the primary antibody. After the secondary antibody incubation, sections were washed several times and nuclei were subsequently stained with DAPI (Sigma, Dorset, UK) for 1 minute. Slides were then washed in $0.1 \mathrm{~mol} / \mathrm{L} \mathrm{PBS}$, followed by several washes in Tris-buffered saline $(\mathrm{pH}$ 7.5). Slides were mounted in Vectashield (Vector Laboratories, Peterborough, UK) and coverslipped. Retinal sections, which were immunostained with calcitonin, were visualized with 3,3-diaminobenzidine.

The other eye was dissected and the retinal pigment epithelium (RPE)-choroidal tissues were used as flat mounts ( $n=4$ from each group), whereas the neural retina was processed for scanning electron microscopy (SEM). The RPEchoroidal flat mounts were fixed as previously described. Eyes were dissected, and the cornea, lens, and retina were removed. The retinas were processed for SEM. Then, five to seven radial cuts were made in the RPE-choroidal tissues to produce flat mounts. After several PBS washes, the RPEchoroidal tissues were blocked and permeabilized with 5\% normal donkey serum in 3\% (v/v) Triton X-100 (BDH Prolabo, VWR International, West Sussex, UK) in PBS for 2 hours. Samples were incubated overnight in a rabbit polyclonal antibody to ionized calcium binding adaptor molecule 1 (Iba-1) (1:1000; A. Menarini Diagnostics, WinnershWokingham, UK) made in 1\% normal donkey serum in 3\% Triton X-100 in $0.1 \mathrm{~mol} / \mathrm{L}$ PBS. After primary antibody incubation, samples were washed repeatedly in PBS and incubated in a secondary antibody, Alexa Fluor donkey antirabbit 488 , made up in $2 \%$ normal donkey serum in $0.3 \%$ Triton X-100 in PBS at a dilution of 1:2000, and incubated for 2 hours. After the secondary antibody incubation, samples were washed repeatedly in PBS and nuclei were stained with DAPI (Sigma) for 1 minute. The RPE-choroidal tissues were then washed in PBS and repeatedly in Tris-buffered saline $(\mathrm{pH}$ 7.5). The flat tissues were then mounted in Vectashield (Vector Laboratories) and coverslipped. Tissues were viewed using epifluorescence, and images were captured as 24-bit color images at $3840 \times 3072$ pixel resolution using a Nikon (Nikon UK Limited, Surrey, UK) DXM1200 digital camera. Iba1 -positive cells were counted across the entire RPE surface at a magnification of $\times 400$.

\section{Western Blot Analysis}

Eyes ( $n=4$ for each group) were dissected on ice, and the retina and RPE-choroidal tissues were separated and snap frozen in liquid nitrogen. The retina and RPE-choroidal tissues were sequentially extracted. Samples were homogenized in $2 \%$ SDS with protease inhibitor cocktail (Roche Diagnostics, West Sussex, UK) and centrifuged at $13,000 \times g$. The supernatant was transferred to a new microcentrifuge tube, and the resultant pellet was extracted with $70 \%$ formic acid. The mixture was then centrifuged at $13,000 \times g$, and the supernatant was transferred to the microcentrifuge tube, discarding the pellet. The formic acid in the supernatant was evaporated using a speed-Vac concentrator (The Eppendorf Vacuum Concentrator model 5301; Brinkmann, Eppendorf, Stevenage, UK), and the protein pellet was reconstituted in $10 \%$ dimethyl sulfoxide in $2 \mathrm{~mol} / \mathrm{L}$ Tris- $\mathrm{HCl}$. The protein concentration was measured with an absorbance of $595 \mathrm{~nm}$, and bovine serum albumin was used as a standard protein concentration.

Equal amounts of proteins $(50 \mu \mathrm{g} / \mathrm{mL})$ were separated by $10 \%$ SDS-PAGE and electrophoretically transferred onto nylon membranes. The nylon membranes were pretreated with $5 \%$ nonfat dried milk in $1 \mathrm{~mol} / \mathrm{L}$ PBS $(\mathrm{pH} 7.4)$ overnight and incubated for 1 hour with monoclonal $A \beta$ antibody $(1: 1000$; Covance), followed by several washes in $0.05 \%$ Tween- 20 in 1 $\mathrm{mol} / \mathrm{L}$ PBS. The membranes were then incubated with a goat anti-mouse IgG peroxidase-conjugated secondary antibody (1:10,000; Thermo Fisher Scientific, Loughborough, UK) for 1 hour. $\mathrm{A} \beta$ immunoreactivity was visualized by exposing $\mathrm{X}$-ray film to blots incubated with electrochemiluminescence reagent (SuperSignal West Pico; Thermo Scientific). The total protein profile was determined by staining gels with Coomassie Blue to check that the extraction of proteins was consistent. Protein bands were then photographed and scanned. The absolute intensity of each band was then measured using Adobe Photoshop CS4 extended (Adobe Systems Software Ireland, Ltd, Dublin, Ireland).

\section{Resin-Embedded Histological Characteristics}

Eyes $(n=4$ in each group) were fixed with $2 \%$ paraformaldehyde and $2 \%$ glutaldehyde in PBS for 24 hours, followed by repeated PBS washing. The cornea and lens were removed. Eye cups were post fixed in $1 \% \mathrm{OsO}_{4}$ in $0.1 \mathrm{~mol} / \mathrm{L}$ PBS for 2 hours. Eye cups were then thoroughly washed in distilled water and dehydrated through a graded series of ethanol. Then, they were infiltrated, polymerized, and embedded in Technovit 7100 historesin (Taab Laboratories Equipment, Berkshire, UK). Resin sections were cut ( $5 \mu \mathrm{m}$ thick), mounted in Depex (BDH Prolabo), and coverslipped.

\section{SEM Data}

The retinas were fixed, osmicated, and dehydrated, as previously described. Specimens were dried with a critical dry point apparatus (CPD 030 Critical Point Dryer; Bal-Tec Ltd, Reading, UK), then gold coated (Cressington 308R Desktop Advancing Coating Systems; Ted Pella, Inc., Agar Scientific, Stansted, Essex, UK). Specimens were analyzed using a Carl Zeiss (Cambridge, UK) scanning electron microscope ( IIGMA VP-Advanced Analytical Microscopy). 


\section{Analysis}

Measurement of the Expression of $A \beta$ in RPE and Photoreceptor Outer Segments and Calcitonin in the Retina by Immunostaining

Analysis of cellular density and immunostaining were focused on the central retina. Fluorescence images were taken in JPEG format at a magnification of $\times 400$, as previously described. Images were montaged. The integrated density, which is the product of the area chosen (in pixels), and the mean gray value (measurement of brightness) of $118.11 \mathrm{px} \times$ $11.811 \mathrm{px}(31.65 \times 3.17 \mu \mathrm{m})$ box for the RPE and $118.11 \mathrm{px} \times$ $118.11 \mathrm{px}(31.65 \times 31.65 \mu \mathrm{m})$ box for the outer segments at five predefined regions per retinal section were measured and averaged using Adobe Photoshop CS4 extended. Measurement of calcitonin undertaken in the same way with a box of $118.11 \mathrm{px} \times 11.811 \mathrm{px}(31.65 \times 3.17 \mu \mathrm{m})$ for the outer plexiform layer and $118.11 \mathrm{px} \times 118.11 \mathrm{px}(31.65 \times 31.65 \mu \mathrm{m})$ box for the ganglion cell layer/inner plexiform layer and outer segments. The average of measurements of all of the three layers was recorded.

Measurement of $A \beta$ in RPE and Retina in Western Blot Analysis

Scanned images of the protein gel were inverted to gray scale format, and the mean gray value was measured for each protein band by using the lasso tool to draw a line all of the way around the edges of the band using Adobe Photoshop CS4 extended. The absolute intensity was calculated by multiplying the mean gray value and the pixel value.

\section{Retinal Measurements and Photoreceptor Outer Segment Numbers}

Three separate resin sections from the central retina containing or adjacent to the optic nerve head were selected from each mouse. Within the central third of the retina, three $100-\mu \mathrm{m}$ wide equally spaced regions were identified. Within these regions, the number of photoreceptor outer segments was counted. Also, along these regions, 10 equally spaced measurements made of the outer nuclear layer (ONL) thickness were undertaken. The means and SDs of these measurements were calculated. To measure the thickness of Bruch's membrane (BM), the tissue was examined at a magnification of $\times 1000$. The membrane is visible at this magnification when the tissue has been placed in osmium and is imaged with differential interference contrast optics. Measurements of BM thickness $(\times 5)$ were made in each mouse.

\section{Statistical Analysis}

A $U$-test was used for comparison of two groups, and a oneway analysis of variance with post hoc analysis with Bonferroni's multiple comparisons was used for four groups. Data were analyzed using GraphPad Prism, version 5.0 (GraphPad, San Diego, CA).

\section{Results}

Genotyping and Phenotype of Mice Deficient in Both Factor $\mathrm{H}$ and $\mathrm{C} 3\left(\mathrm{CFH}^{-/-} . \mathrm{C3}^{-/-}\right), \mathrm{CFH}$ Alone $\left(\mathrm{CFH}^{-/-}\right)$, C3 Alone $\left(\mathrm{C}^{-/-}\right)$, and WT $(C 57 B L / 6)$

The genotype of all four groups of mice was determined by PCR for $\mathrm{C} 3$ and factor $\mathrm{H}$. After backcrossing them for $>10$ generations, the $\mathrm{C}^{-/-}, \mathrm{CFH}^{-1-}$, and the double-knockout $\mathrm{CFH}^{-1-}$. $\mathrm{C3}^{-1-}$ mice were shown to be homozygous to their relative knockout (Figure 1A). The upper gel in Figure 1A is the PCR for complement C3. The WT C57 mice had a 920-bp DNA band, whereas the homozygous knockouts had an 1100-bp DNA band. The lower gel is the PCR for factor $\mathrm{H}$. The WT C57 mice had a 600-bp DNA band, whereas the homozygous knockouts showed a 400-bp DNA band. The $\mathrm{CFH}^{-1-} . \mathrm{C}^{-/-}$mice amplified an 1100-bp band from the C3 PCR gel and a 400-bp band from the CFH PCR gel, which confirmed that they were homozygous knockout for both $\mathrm{C} 3$ and FH. The $C 3^{-/-}$mice had an 1100-bp band from the C3 PCR gel and a 600-bp band from the FH PCR gel, which showed that they are $\mathrm{C} 3$ knockouts but were positive for factor $\mathrm{H}$, whereas the $\mathrm{CFH}^{-/-}$mice have a 920bp band from the C3 PCR gel and a 400-bp band from the FH PCR gel.

To verify that the genotype of the mice was expressed phenotypically, retinal sections of each group were immunostained with complement component $\mathrm{C} 3$ and complement factor $\mathrm{H}$ antibodies (Figure 1B). The WT C57 mice expressed both $\mathrm{C} 3$ (green) and factor $\mathrm{H}$ (red). $\mathrm{CFH}^{-/-}$mice did not express $\mathrm{CFH}$, but they did express $\mathrm{C} 3$ along their $\mathrm{BM}$ and outer segments. $C 3^{-/-}$mice did not express $\mathrm{C} 3$, but they expressed CFH. $\mathrm{CFH}^{-1-}$. $\mathrm{C}^{-/-}$mice expressed neither $\mathrm{C} 3$ nor $\mathrm{CFH}$. These results confirmed that the mice used were homozygous knockouts, whether single or double.

\section{C3 Deficiency in the AMD Model Results in Photoreceptor Dysfunction}

The ERGs were used to assess retinal function in C57BL/6, $\mathrm{CFH}^{-1-}, \mathrm{C3}^{-/-}$, and $\mathrm{CFH}^{-1-} . \mathrm{C}^{-/-}$mice $(n=4$ per group) in response to full-field stimuli under scotopic (relatively low luminance, rod function) and photopic (relatively high luminance, cone function) conditions. Responses to light stimuli in C57BL/6, $\mathrm{CFH}^{-/-}, \mathrm{C}^{-/-}$, and combined $\mathrm{CFH}^{-/-}$. $\mathrm{C}^{-/-}$mice were recorded. The scotopic a-wave in the mutant strain mice that is generated by photoreceptors was reduced compared with C57BL/6 WT mice, revealing impaired photoreceptor function (Figure 2A). The reduction was most marked in $\mathrm{CFH}^{-/} . \mathrm{C}^{-/-}$mice at high intensities $(P<0.05$ at intensity 9 , and $P<0.01$ at intensity 10 ) (Figure 2A). This reduction in the a-wave amplitude in $\mathrm{CFH}^{-1} . \mathrm{C3}^{-/-}$is consistent with photoreceptor function being more seriously compromised in these animals than in any of the other groups.

The a- and b-waves of the $\mathrm{CFH}^{-1-}$ mice also showed a small decrease in amplitudes compared with the C57BL/6 
A

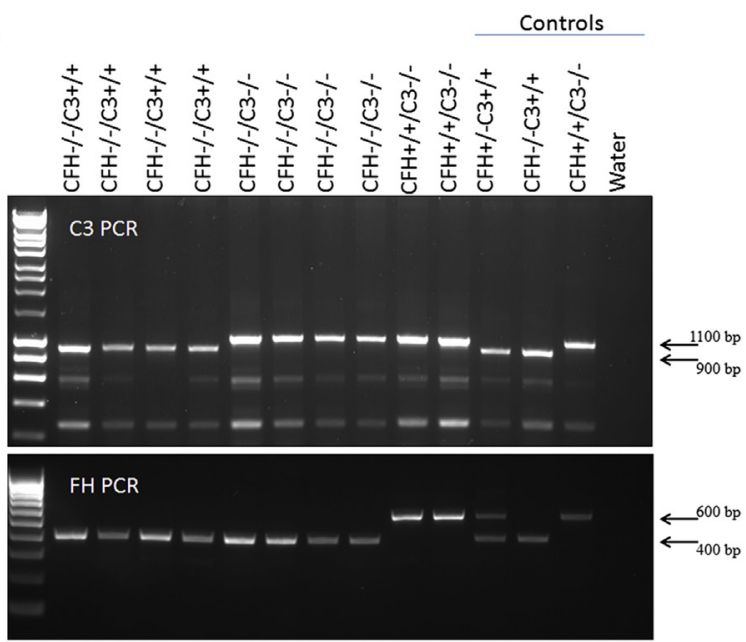

B

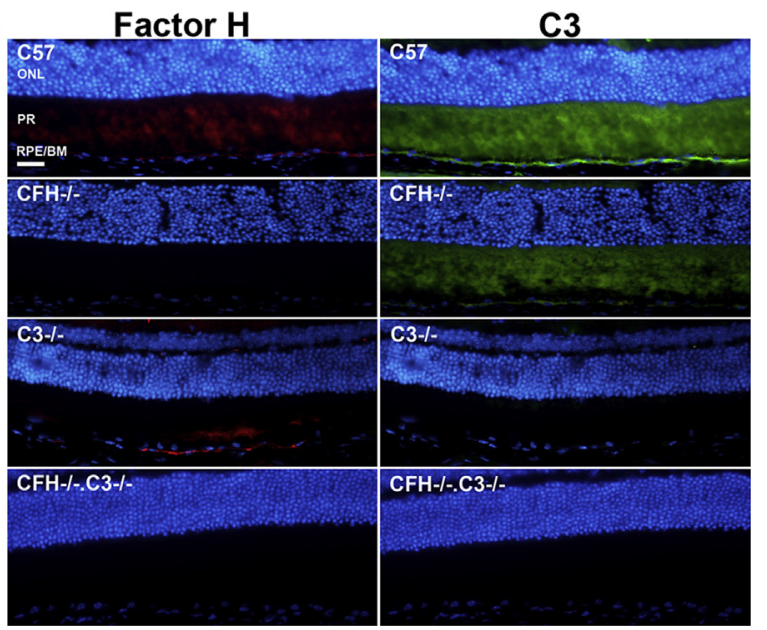

Figure 1 A: Factor $\mathrm{H}$ and complement $\mathrm{C} 3$ genotyping on all of the knockout mice. Top gel: C3 PCR: WT amplified 920-bp DNA band, whereas the homozygous knockout amplified an 1100-bp DNA band. Bottom gel: FH PCR: WT amplified 600-bp DNA band, whereas the homozygous knockouts amplified a 400-bp DNA band. The $\mathrm{CFH}^{-1-} . \mathrm{C3}^{-/-}$mice amplified 1100-bp (from the C3 PCR gel) and 400-bp (from the FH PCR gel) bands, confirming that they were homozygous knockout for both $\mathrm{C} 3$ and $\mathrm{FH}$. The $\mathrm{C}^{-/-}$mice amplified 1100-bp (from the C3 PCR gel) and 600-bp (from the FH PCR gel) bands, demonstrating that they were $\mathrm{C} 3$ knockouts but were positive for factor $\mathrm{H}$, whereas the $\mathrm{CFH}^{-/-}$mice amplified 920-bp (from the C3 PCR gel) and 400-bp (from the FH PCR gel) bands. B: Expression of factor $\mathrm{H}$ and $\mathrm{C} 3$ in all of the four groups of mice on the BM and in the photoreceptor outer segments. Retinal sections were immunostained with $\mathrm{C} 3$ and $\mathrm{CFH}$ antibodies. $\mathrm{C} 57$ mice expressed both $\mathrm{C} 3$ (green) and factor $\mathrm{H}$ (red). $\mathrm{CFH}^{-1-}$ mice did not express $\mathrm{CFH}$, but they expressed $\mathrm{C} 3$ along their $\mathrm{BM}$ and outer segments. $\mathrm{C3}^{-/-}$mice did not express $\mathrm{C} 3$, but they expressed $\mathrm{CFH}$. $\mathrm{CFH}^{-1-} . \mathrm{C}^{-1-}$ mice expressed neither $\mathrm{C} 3$ nor $\mathrm{CFH}$. These results confirmed that they were homozygous knockouts, whether single or double. Scale bar $=50 \mu \mathrm{m}$.

mice, but these were not statistically significant. Closer examination of the b-wave, generated by the inner retina, in the $\mathrm{CFH}^{-1-}$ mice revealed that it was almost devoid of the oscillatory potential indentations (Figure 2B) that ride on the ascending limb of the $b$-wave. This indicates that the retinal vasculature may be compromised.

Under photopic conditions, the $\mathrm{CFH}^{-1-} . \mathrm{C}^{-/-}$mice again showed a markedly significantly lower response in the a-wave amplitude than all of the other groups under all stimulus intensities $(P<0.01$ at intensity $3, P<0.001$ at intensity 4 , and $P<0.001$ at intensity 5) (Figure 2A). Again, the b-wave of $\mathrm{CFH}^{-/-}$mice was devoid of oscillatory potentials, as seen under scotopic conditions. Although the a-waves of the $\mathrm{CFH}^{-1-} . \mathrm{C}^{-/-}$mice showed significant deficits, the b-waves of all of the four groups of mice under both scotopic and photopic conditions were not significantly different (data not shown). These data demonstrate significant photoreceptor functional impairment in $\mathrm{CFH}^{-/-} . \mathrm{C}^{-/-}$ mice.

\section{$\mathrm{CFH}^{-/-} . \mathrm{C3}^{-/-}$Aged Mice Display Structural Retinal Changes and Accumulate Debris on the Photoreceptor Outer Segments}

Retinas were examined to reveal why $\mathrm{CFH}^{-1-} . \mathrm{C}^{-/-}$ photoreceptor function was impaired (Figure 3). Resin sections at the light microscope level revealed that $\mathrm{CFH}^{-/}$, $\mathrm{CFH}^{-1-} \cdot \mathrm{C}^{-/-}$, and $\mathrm{C}^{-/-}$mice exhibited outer retinal thinning (Figure 3$)$ and reductions in ONL thickness $(P<$ 0.0001 for all knockouts) (Figure $3, \mathrm{~A}-\mathrm{C}$ ) and in nuclei numbers present across the depth of the ONL $(P<0.0001$ for all knockouts), along with significantly reduced outer segment numbers compared with $\mathrm{C} 57 \mathrm{BL} / 6$ mice $\left[\mathrm{CFH}^{-1-}\right.$. $C 3^{-/-}$and $C 3^{-/-}(P<0.0001)$ and $\left.C F H^{--}(P=0.0026)\right]$ (Figure 3). However, in each case, these reductions were greater in $\mathrm{CFH}^{-1-} . \mathrm{C}^{-/-}$mice than others compared with the C57BL/6 mice.

The knockout mice also showed significantly thicker BM than C57BL/6 $\left(\mathrm{CFH}^{-/-}, P=0.0286 ; \mathrm{C3}^{-/-}, P=0.0286\right.$; and $\mathrm{CFH}^{-1-} . \mathrm{C}^{-/-}, P=0.0159$ ) (Figure $3, \mathrm{~B}$ and $\mathrm{C}$ ). The relative thickening of $\mathrm{BM}$ across groups was a mirror reversal of the data gathered for the size of photoreceptor populations. Hence, the $\mathrm{CFH}^{-/-} . \mathrm{C}^{-/-}$mice, which had the greatest reductions in the photoreceptor population, had the thickest BM, whereas in the two other groups, BMs were thicker than in the C57BL/6 mice, but to a lesser extent. These data are consistent with the notion that thickening of $\mathrm{BM}$ is proportionally detrimental to the survival of the outer retina.

The $C 3^{-/-}$mice possessed outer retinal features not seen in other groups. They appeared to experience regional failures of phagocytosis, leading to local subretinal accumulation of outer segments (Figure 3D). Examination of the RPE under the retinas of these animals showed pigment migration away from the RPE surface (Figure 3E), depigmentation of individual cells, disruption to the cellular mosaic, and ruffling of RPE cell membranes normally associated with cell movement within the RPE mosaic ${ }^{27,28}$ (Figure 3F). These data imply that, in this phenotype, there is a specific disruption of the RPE.

SEM revealed accumulation of fibrillary material on all mouse outer segments (Figure 4), which stops at the inner segment. Closer examination of these deposits at a higher magnification revealed that the accumulated material on the 
A
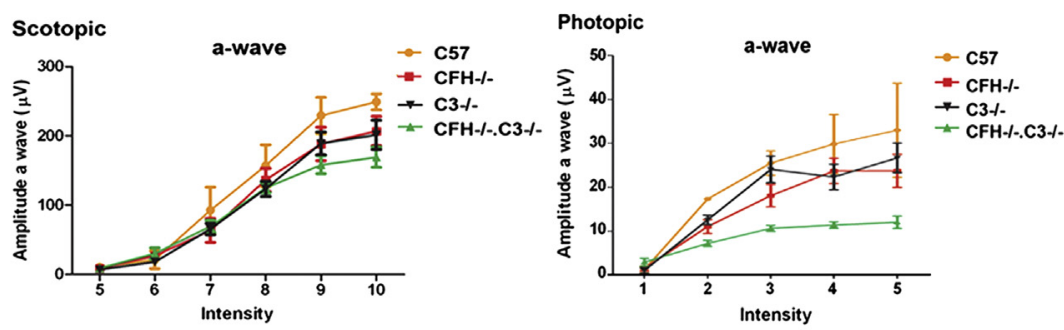

B
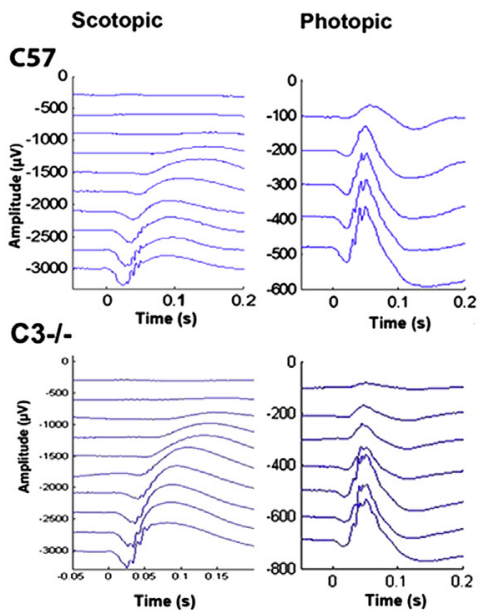

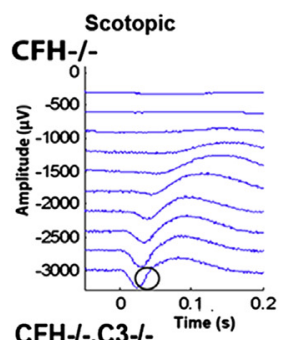

CFH-1-.C3-1- Time (s)
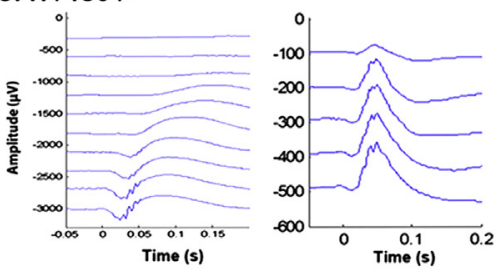

Figure 2 ERG assessment of retinal function in 12-month-old $\mathrm{C} 57 \mathrm{BL} / 6, \mathrm{CFH}^{-/-}, \mathrm{C3}^{-/-}$, and $\mathrm{CFH}^{-1-} . \mathrm{C3}^{-/-}$mice. A: Responses over progressive light intensities for photoreceptor-generated awave under scotopic and photopic conditions. B: Examples of evoked responses of a- and b-waves and oscillatory potentials in scotopic and photopic conditions. There were no significant differences in b-waves between groups. Under scotopic and photopic conditions, $\mathrm{CFH}^{-/-} . \mathrm{C3}^{-/-}$mice exhibited a significant reduction in a-wave amplitude, with increasing stimulus intensity compared with C57, indicating that rod and cone functions are impaired. $\mathrm{CFH}^{-1-}$ mice lacked oscillatory potentials that ride on the ascending b-wave limb (circled areas). This is consistent with reduced retinal perfusion shown in these mice by Lundh et $\mathrm{al.}^{26}$ outer segments of the C57BL/6 mice largely appeared as ruptured hemispheres that have partially collapsed, leaving rough edges (Figure 4, A and B). Within this pattern, small spherical structures are present (Figure 4, A and B). These deposits were heavier toward the apical end of the outer segments close to the RPE.

$\mathrm{CFH}^{-/-}$mice were similar to the $\mathrm{C} 57 \mathrm{BL} / 6$ mice, with slightly heavier deposition close to the RPE (Figure 4, C and D). There were marked differences in the nature of outer segment deposits in the other two knockout groups compared with those in $\mathrm{CFH}^{-1-}$ and $\mathrm{C} 57 \mathrm{BL} / 6$ mice. $\mathrm{C}^{-/-}$ mice had few deposits. When present, they were apical, spherical, and clustered (Figure 4, E and F). Outer segments of $C 3^{-1-}$ mice were often distorted, with swellings (Figure 4G) at specific regions, and large groups were present running orthogonal to the RPE surface under the retina (Figure $4 \mathrm{H}$ ). These were not associated with nuclei and appeared to be free structures that had been displaced. These observations are consistent with a failure or disruption of RPE phagocytosis, leaving a region of free segments trapped under the retina.

Deposition patterns found in $\mathrm{CFH}^{-/-} . \mathrm{C}^{-/-}$mice were distinctive from those in the other groups and dense. Outer segments of $\mathrm{CFH}^{-/-} . \mathrm{C}^{-/-}$mice were completely coated in a tight fibrous material with bulbous ends (Figure 4, I and L), thicker than in other groups, extending continuously from the apical tip down to the inner segment (Figure 4, J and K). Although quantitative data regarding outer segment lengths were not obtained, in all of the ultrastructural images, the outer segments of the $\mathrm{CFH}^{-1-}$ and $\mathrm{C} 57 \mathrm{BL} / 6$ animals appeared similar. However, in the $C 3^{-/-}$mice, they were clearly longer, whereas in the $\mathrm{CFH}^{-/-} . \mathrm{C}^{-/-}$animals, they were shorter. The shorter outer segments in the latter group, combined with their reduced number and dense extracellular coating, may contribute to the reduced magnitude of the ERG responses in this group. The longer segments in $C 3^{-/-}$mice are again consistent with a failure or disruption to phagocytic mechanisms.

\section{$\mathrm{CFH}^{-/-} . \mathrm{C}^{-/-}$Aged Mice Have Increased Outer Retinal A $\beta$ Deposition}

Retinal amyloid $\beta(\mathrm{A} \beta)$ accumulation is a feature associated with $\mathrm{AMD}$. In the WT aged retina, $\mathrm{A} \beta$ accumulates at two primary locations, along BM and on photoreceptor outer segments. $^{29}$ All knockout mice had reduced $A \beta$ on their outer segments, but significantly more on RPE/BM compared with $\mathrm{C} 57 \mathrm{BL} / 6$ mice, consistent with their $\mathrm{BM}$ thickening (Figure 5, A and B). $\mathrm{C3}^{-/-}$and $\mathrm{CFH}^{-1-}$ mice accumulated more $\mathrm{A} \beta$ on RPE/BM than $\mathrm{C} 57 \mathrm{BL} / 6$ mice $(P<$ 0.0003 and $P<0.0002$, respectively) (Figure 5, A and B), whereas $\mathrm{CFH}^{-/-}$accumulated similar amounts on their outer segments as $\mathrm{C} 57 \mathrm{BL} / 6$ mice and $C 3^{-/}$had significantly less $(P<0.0001)$ (Figure 5A), with intense staining at their tips, consistent with SEM images (Figure 4C). $\mathrm{CFH}^{-/-} . \mathrm{C}^{-/-}$ mice accumulated hardly any $\mathrm{A} \beta$ on outer segments $(P=$ 0.0002) (Figure 5, A and B), but significantly more than any group on RPE/BM ( $P=0.0001$, compared with $\mathrm{C} 57 \mathrm{BL} / 6)$. $\mathrm{A} \beta$ expression on $\mathrm{RPE} / \mathrm{BM}$ was strong and appeared thicker in $\mathrm{CFH}^{-/-} . \mathrm{C}^{-/-}$mice than other groups. $\mathrm{A} \beta$ on RPE/BM 


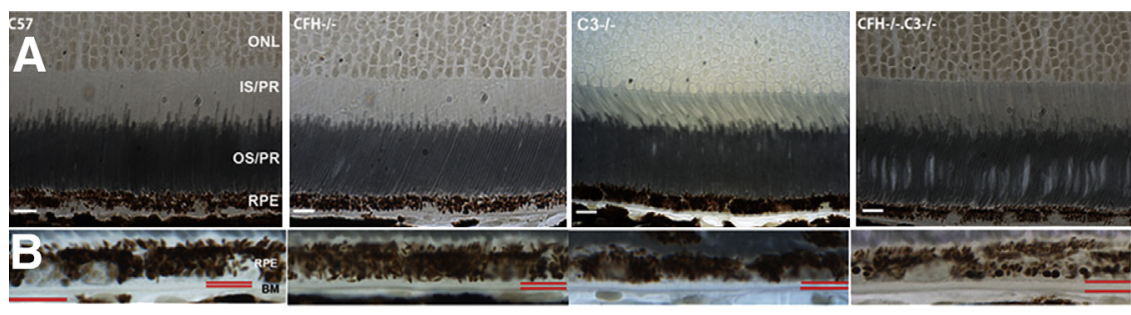

Figure 3 Structural organization of the outer retina and abnormalities in the outer retina of $\mathrm{C}^{-/-}$ mice. A: Resin sections of the outer retina of each group, spanning the retinal pigment epithelium (RPE) into the outer nuclear layer (ONL). B: Images of Bruch's membrane (BM). The thickness of the BM is marked (red line). C: Graphs of ONL thickness in each group, number of photoreceptor outer segments (OS/PR), number of nuclei running down through the $0 \mathrm{NL}$, and thickness of BM. All knockouts differed significantly from C57 mice with a thinner ONL, fewer cells in the $0 \mathrm{NL}$, fewer outer segments, and a significantly thicker BM. However, in each $\mathrm{CFH}^{-1-} . \mathrm{C3}^{-1-}$ mouse, the animals were more deficient. ${ }^{*} P<0.05,{ }^{*} P<0.005$, and ${ }^{* * *} P<$ 0.0005. D-F: $\mathrm{C3}^{-/-}$mice were distinctive because they had regional deficits in RPE associated with failures to clear outer segments. D: Image of a retinal section of $\mathrm{C}^{-/-}$mice. At multiple locations, OSs accumulated ectopically between the RPE and outer retina. They were aligned orthogonally to a normal population. E: RPE migration into the retina (arrow). F: RPE sheet showing pigment shedding and regional cell loss (asterisks). RPE membranes have an irregular appearance, consistent with cells having less cell-cell adhesion (arrows). Scale bars: $20 \mu \mathrm{m}$ [B (for resin sections), D, and $\mathbf{E}$ ]; $50 \mu \mathrm{m}(\mathbf{F})$. IS, inner segment; 0S, outer segment; PR, photoreceptor.

extended down into the choroid between blood vessels. It is not clear where $A \beta$ originates, but its absence from outer segments in $\mathrm{CFH}^{-1-} . \mathrm{C}^{-1-}$ mice suggests that either photoreceptor fails to secrete it or it is digested more rapidly by the RPE. Enhanced RPE digestion is consistent with its accumulation on BM, and with BM thickening. However, it also suggests that the distinct types of deposition found at the EM level in $\mathrm{CFH}^{-/-} . \mathrm{C}^{-/-}$mice (Figure 4D) are not $\mathrm{A} \beta$, but either are another deposit type or may originate from local cellular damage.

To further quantify the amount of $A \beta$ in the RPE/BM and the retina, Western blot analysis was undertaken. The results revealed that the prominent oligomers present at either location are approximately 27 and $56 \mathrm{kDa}$ (Figure 5, C and D). $A \beta$ present in the retina was dominated by the approximately $56-\mathrm{kDa}$ oligomers, whereas that along the RPE/BM interface was dominated by the approximately 26 $\mathrm{kDa}$ oligomers. The Western blot analysis largely reflected the results obtained with immunostaining and confirmed that $\mathrm{CFH}^{-/-} . \mathrm{C}^{-/-}$mice accumulated more $\mathrm{A} \beta$ on RPE/ $\mathrm{BM}$ compared with the other three groups, but lesser in the retina (Figure 5, C and D). The most prominent $\mathrm{A} \beta$ oligomer present in the retina of the $\mathrm{CFH}^{-1-} . \mathrm{C3}^{-/-}$mice was the heavier approximately $56-\mathrm{kDa}$ dodecamers that are thought to be the more neurotoxic (Figure 5, C and D). ${ }^{30}$ Impaired photoreceptor function may originate from increased $\mathrm{A} \beta$ accumulation on RPE/BM of $\mathrm{CFH}^{-/-} . \mathrm{C3}^{-/-}$ mice, resulting in its thickening; this prevents transepithelial transportation between the choriocapillaris and the RPE, resulting in disrupted RPE function and photoreceptor cell death.

\section{$\mathrm{CFH}^{-/-} . \mathrm{C3}^{-/-}$Aged Mice Have Fewer Macrophages But Elevated Retinal Inflammation}

Subretinal macrophages were significantly reduced in $C 3^{-/-}$, $\mathrm{CFH}^{-1-}$, and $\mathrm{CFH}^{-\prime-} . \mathrm{C3}^{-1-}$ compared with C57BL/6 mice $(P=0.0317, P=0.0177$, and $P=0.0051$, respectively $)$ (Figure 6A). However, $\mathrm{CFH}^{-1-} . \mathrm{C}^{-/-}$mice were more seriously affected, suggesting that the absence of either $\mathrm{C} 3$ or $\mathrm{CFH}$ restricts the activation and recruitment of subretinal macrophages.

Because there are marked differences between the groups in terms of $A \beta$ deposition and macrophage numbers, this may be reflected in different patterns of inflammation. Sections were stained for inflammatory markers: TNF- $\alpha$ and calcitonin. TNF- $\alpha$ is a proinflammatory cytokine synthesized in monocytes and activated macrophages ${ }^{31}$ and stimulates RPE to produce monocyte chemotactic protein-1 to recruit macrophages into the sub-RPE space. ${ }^{32,33}$ Calcitonin is an acute-phase protein elevated in ageing retinas and a complement-independent inflammatory biomarker. ${ }^{34}$ TNF- $\alpha$ is expressed mainly in the photoreceptor layer (Figure 6B). $C 3^{-1-}$ mice expressed significantly higher TNF- $\alpha$ levels $(P=0.0029)$ (Figure 6 , $\mathrm{B}$ and C) than C57BL/6 mice. TNF- $\alpha$ expression in $\mathrm{CFH}^{-1-}$. $\mathrm{C}^{---}$was higher compared with $\mathrm{C} 57 \mathrm{BL} / 6$ and $\mathrm{CFH}^{-1-}$ mice but was not significant. No difference was found between C57BL/6 and $\mathrm{CFH}^{-1-}$ mice. 
Calcitonin was expressed across the retina in both plexiform layers, the ganglion cell layer, and photoreceptors. Its overall expressions in $\mathrm{CFH}^{-1-} . \mathrm{C}^{-/-}$and $\mathrm{C}^{-1-}$ mice were significantly higher than in $\mathrm{C} 57 \mathrm{BL} / 6$ and $\mathrm{CFH}^{-1-}$ mice $\left(P<0.0001\right.$ for both $\mathrm{CFH}^{-/-} . \mathrm{C3}^{-/-}$and $\mathrm{C3}^{-/-}$) (Figure 6, $\mathrm{D}$ and $\mathrm{E})$. There was no significant difference in calcitonin levels in $\mathrm{CFH}^{-1-}$ mice compared with C57BL/6 mice $(P=$

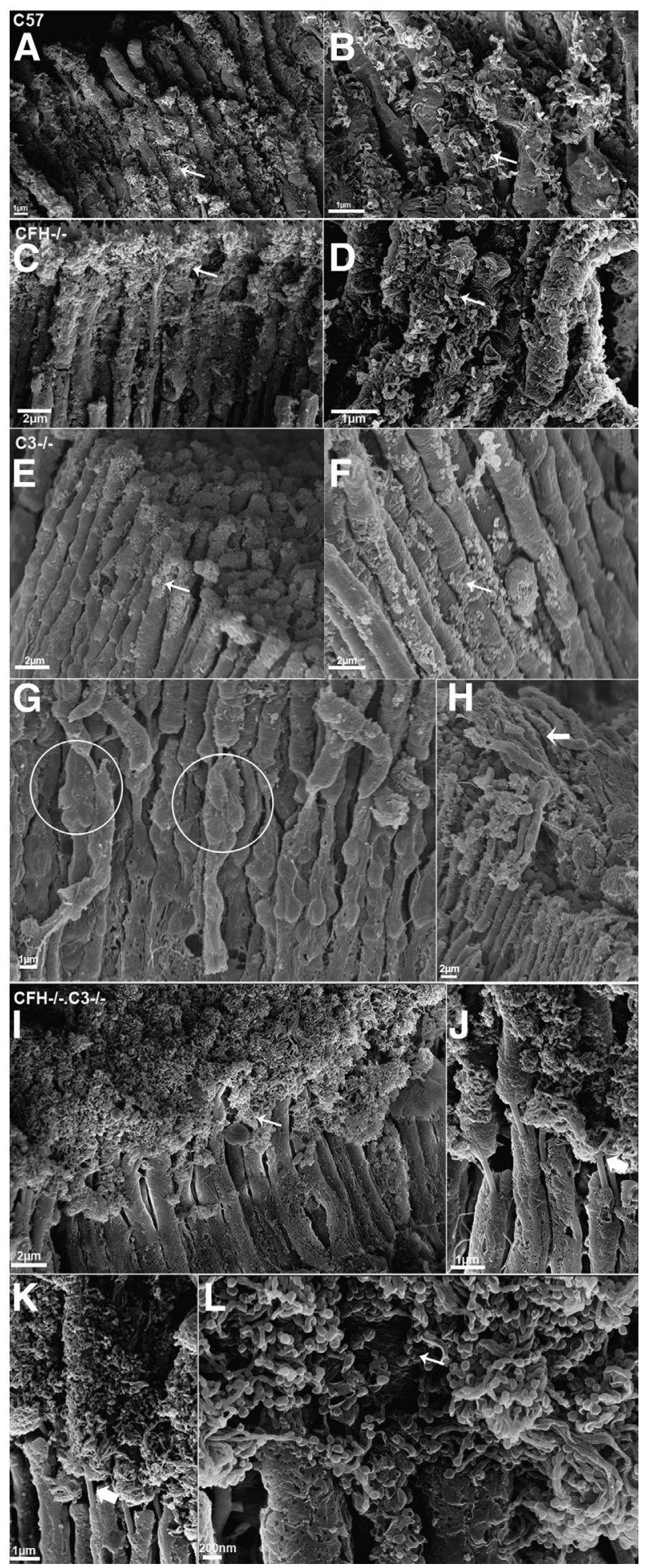

0.1344). Hence, in the absence of $\mathrm{C} 3$, retinal inflammation is even higher than in $\mathrm{C} 57 \mathrm{BL} / 6$ and $\mathrm{CFH}^{-1-}$ mice.

\section{Discussion}

Approximately $50 \%$ of AMD cases are associated with polymorphisms of $\mathrm{CFH}$, particularly $\mathrm{Y} 402 \mathrm{H} \mathrm{CFH} .{ }^{20} \mathrm{CFH}$ is the major regulator of $\mathrm{C} 3$ activation through the alternative complement pathway. Complete deficiency of $\mathrm{CFH}$ in humans, ${ }^{35,36}$ pigs, ${ }^{37}$ and mice ${ }^{38}$ results in uncontrolled C3 activation through this pathway and secondary severe plasma C3 deficiency. ${ }^{38}$ Human CFH deficiency is associated with renal diseases, which include dense deposit disease and thrombotic microangiopathy. ${ }^{35-38}$ Experimental murine models of these renal conditions have shown that they are dependent on the ability to activate C3. Previously, it has been shown that aged CFH-deficient mice develop retinal abnormalities. ${ }^{39}$ This suggested that C3 dysregulation resulted in pathological features. Herein, we examined retinal pathological features in mice with $\mathrm{CFH}$ deficiency, $\mathrm{C} 3$ deficiency, and combined deficiency of CFH and $\mathrm{C} 3$. Our results showed that absence of $\mathrm{C} 3$ resulted in retinal pathological features. Furthermore, retinal abnormalities in mice with a combined deficiency of CFH and $\mathrm{C} 3$ were significantly greater than those seen in mice with a CFH deficiency alone. These data indicate that both $\mathrm{CFH}$ and $\mathrm{C} 3$ are required to maintain retinal health in the mouse, and that $\mathrm{CFH}$ mediates an important role in murine retinal physiological features, independent of its function as a regulator of $\mathrm{C} 3$.

$\mathrm{CFH}^{-1} . \mathrm{C}^{--}$mice had significantly reduced retinal function, focusing on the photoreceptor-generated a-wave under scotopic and photopic ranges. All knockouts showed reduced photoreceptor numbers and significant BM thickening, but these were markedly more prominent in $\mathrm{CFH}^{-1-}$.

Figure 4 Scanning electron micrograph of outer segments. A: Outer segments of $\mathrm{C} 57$ are coated with extracellular material (arrow) previously associated with $A \beta$. This is denser apically than basally. B: At higher magnification, this material appears to be largely composed of elements with rough edges, although spherical material is also present (arrow). Orientation: outer segments viewed from the scleral side with RPE removed. C: Low-magnification images of the outer segments in $\mathrm{CFH}^{-/-}$mice. Debris accumulates apically (arrow). D: Higher-magnification image of $\mathrm{CFH}^{-1-}$ mice, revealing debris similar to that found in $\mathrm{C57}$ (arrow). Orientation: outer segments viewed from the scleral side with RPE removed. E: Debris accumulated on outer segments of $\mathrm{C}^{-/-}$mice (arrow). F: Higher-magnification image reveals that deposits are smaller and fewer than in $\mathrm{C} 57$ and $\mathrm{CFH}^{-1-}$ mice. The arrow indicates the debris accumulated on the outer segments of the $\mathrm{C}^{-/-}$mice. G: Many outer segments were irregular (circled areas), and some were distorted. H: Large groups of outer segments were present coursing orthogonally on top of the RPE (arrow) (Figure 3D). Orientation: outer segments viewed from the scleral side with RPE removed. I-L: Outer segments of $\mathrm{CFH}^{-/-} . \mathrm{C3}^{-/-}$mice were completely coated with debris that had long filaments with globular nodules at extremities (arrows). $\mathbf{J}$ and $\mathbf{K}$ : This tight material extended down to the inner segment (arrows). L: Higher-power images revealed that deposited material was different from that in other groups (arrow). Orientation: outer segments viewed from the scleral side with RPE removed. 
A

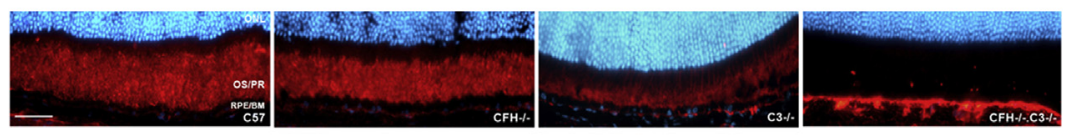

B
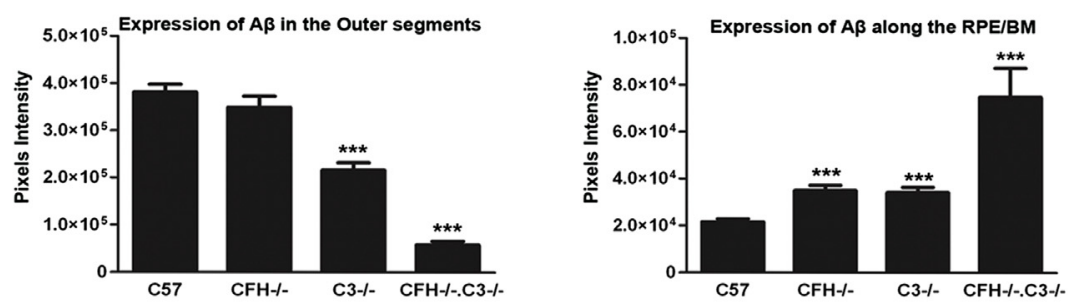

C

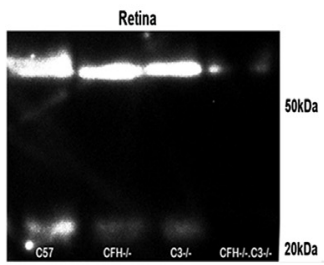

D

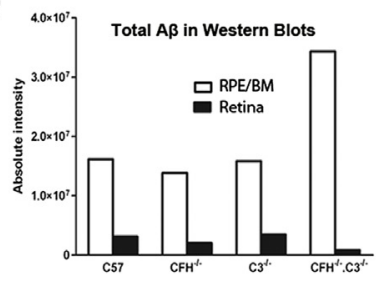

Figure $5 \quad A \beta$ accumulation on outer segments and along RPE/BM. A: Retinal sections immunostained with $A \beta$ (red) and nuclei with DAPI (blue). B: Graphs showing quantitative measurement of $A \beta$ expression on outer segments and along RPE/BM. Less $A \beta$ was found on outer segments, but more was present along RPE/BM in all knockout mice compared with $\mathrm{C57}$. In $\mathrm{CFH}^{-/-} . \mathrm{C3}^{-/-}$, almost all of $A \beta$ deposition was along RPE/BM, with some extending into the choroid. There was little on outer segments. ${ }^{* * *} P<0.0005$. C: Western blot analyses confirmed these data and showed the different $A \beta$ oligomers present. In all groups, larger proportions of approximately $56-\mathrm{kDa} A \beta$ were present in the retina and larger proportions of approximately $27 \mathrm{kDa}$ were present along the RPE/ $B M$. D: Western blot analyses showed higher total $\mathrm{A} \beta$ deposition from $\mathrm{CFH}^{-1-} . \mathrm{C}^{-/-}$mice than any other groups, mainly confined to the RPE/BM. Scale bar $=50 \mu \mathrm{m} .0 \mathrm{~S} / \mathrm{PR}$, outer segment photoreceptor.
$C 3^{-1-}$ mice, reflecting their reduced ERG function. Thickening of BM is caused by cross-linking of collagen fibers and increased deposition of waste products of RPE metabolism, ${ }^{40}$ which leads to a reduction in its filtration capacity and, therefore, affects the transepithelial transportation between the retina and the choriocapillaris. ${ }^{40}$ Therefore, photoreceptors that have a high metabolic demand ${ }^{41,42}$ are deprived of essential materials to function and, subsequently, die. It had been argued that $\mathrm{CFH}^{-/-}$mice had an abnormally thin BM, ${ }^{39}$ which is inconsistent with our finding. However, Coffey et $\mathrm{al}^{39}$ examined animals at 24 months, although herein we have focused on animals that are only 12 months old. The same study also claimed that outer segments of $\mathrm{CFH}^{-/-}$mice were disorganized, which again is a feature we did not find. It is possible that excess degenerative changes occur beyond 12 months, accounting for this discrepancy.

Photoreceptor outer segments in all of the groups were coated with fibrillary material that appeared to accumulate apically but always stopped at the inner-outer segment junction. These deposits were similar in the $\mathrm{CFH}^{-/-}$and C57BL/6 mice, but were markedly different in the $\mathrm{CFH}^{-1-}$. $C 3^{-1-}$ and $C 3^{-1-}$ mice, with the former having heavily coated photoreceptors and the latter having little deposition. All had $\mathrm{A} \beta$ as a significant component of this material, except the $\mathrm{CFH}^{-/-} . \mathrm{C}^{-/-}$mice. All groups had $\mathrm{A} \beta$ deposition on BM, but the $C F H^{-/} . C 3^{-/-}$mice accumulated significantly more compared with the other groups. $\mathrm{CFH}^{-/-}$. $C 3^{-/-}$and $C 3^{-/-}$mice had higher levels of inflammation when compared with $\mathrm{CFH}^{-/-}$and C57BL/6 mice. All of the three knockout mice had fewer subretinal macrophages than the C57BL/6 mice.

The ERG data provide the critical readout of retinal function, demonstrating that, over a wide range of intensities, photoreceptor function in the $\mathrm{CFH}^{-/-} . \mathrm{C}^{-/-}$animals was seriously compromised. The magnitudes of a- and b-waves to scotopic stimuli have been reported to be reduced in $\mathrm{CFH}^{-1-}$ mice that were 2 years old. ${ }^{39}$ Similar trends can be seen in data presented for the younger animals here in the b-waves. In addition, our data also clearly demonstrate that the ascending limb of the b-wave of $\mathrm{CFH}^{-/}$mice was almost devoid of the typical oscillatory potential indentation normally present under both scotopic and photopic conditions. They are understood to be generated by amacrine cells and their temporal interactions. Reduced amplitudes of these potentials are known to indicate development of soft exudates and nonperfused areas, and are found in patients with diabetes. ${ }^{43}$ Furthermore, studies have shown that patients with retinal artery occlusion have low-amplitude or extinguished oscillatory potentials. ${ }^{44,45}$ Hence, their absence is indicative of compromised retinal vasculature that correlates with the previous results from our laboratory showing outer retinal vascular pathological features in the $\mathrm{CFH}^{-/-}$mice, ${ }^{26}$ which are the result of $\mathrm{C} 3$ and its active fragments being deposited on retinal and choroidal vessels, leading to occlusion and reduced circulation. The fact that the other groups displayed normal oscillatory potentials is consistent with their circulation not being compromised.

When $\mathrm{C} 3$ is absent in $\mathrm{CFH}^{-/-}$mice, oscillatory potentials reappeared, because in its absence, there were no depositions of $\mathrm{C} 3$ and its active fragments along the walls of blood vessels and, therefore, no restriction. Another potential reason why the oscillatory potentials are restored in the $\mathrm{CFH}^{-/-} . \mathrm{C} 3^{-/-}$mice is that, with the increased photoreceptor loss, retinal blood supply demand may be reduced, re-establishing a normal balance of supply and demand despite the occlusion of blood vessels.

The outer retina of $C 3^{-/-}$mice had an accumulation of undigested outer segments, suggesting impaired phagocytosis, consistent with their marked RPE pathological features and 
regional RPE loss. All knockouts had thickened BM, which probably results from increased waste deposition, ${ }^{40}$ leading to reduced transepithelial transportation. ${ }^{40}$ Therefore, photoreceptors, with their high metabolic demand, ${ }^{41,42}$ are metabolically deprived, increasing the probability of cell death. Deposits on $\mathrm{C} 57 \mathrm{BL} / 6, \mathrm{C}^{-/-}$, and $\mathrm{CFH}^{-1-}$ outer segments were morphologically similar. However, that on $\mathrm{CFH}^{-1-} . \mathrm{C}^{-/-}$ mice was different, completely coating outer segments with fibrous material with nodular ends. This material is $A \beta$ negative
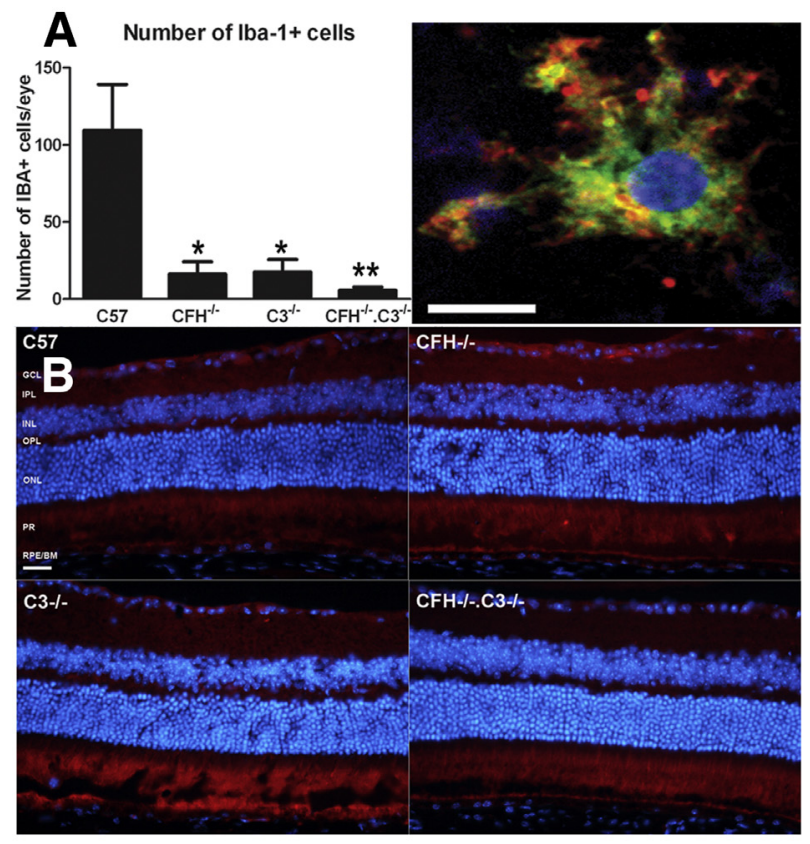

C
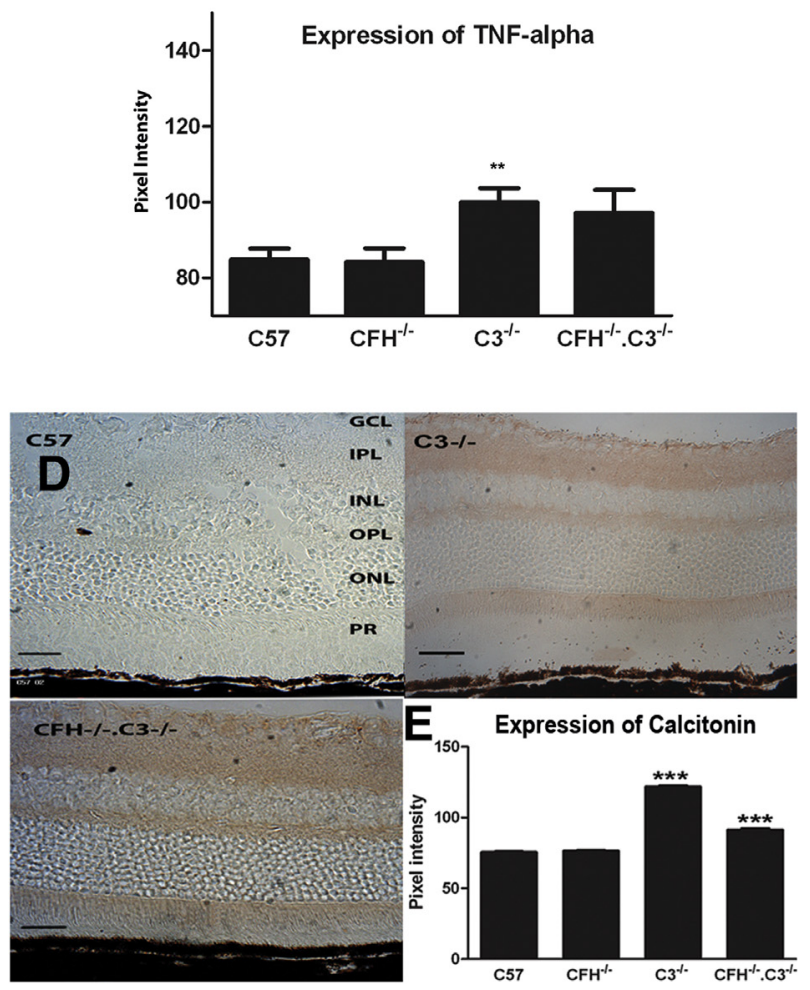

and likely related to their reduced function. From the SEM material gathered herein and by Hoh Kam et al, ${ }^{29}$ it appears that outer segment debris initially accumulates at the interface between the segment tip and the RPE. Progressively, it is found with increasing frequency down the length of the outer segment toward the inner segment. This may be due to inefficiency in the process of phagocytosis. It is possible that a small proportion of each outer segment removed by the RPE is not digested, but spills into the extracellular space and accumulates slowly. It would also potentially explain the finding in the $C 3^{-/-}$mice, in which phagocytosis appears to be significantly reduced and outer segments have far fewer deposits. However, when present, they are much more common apically. In every mouse type examined herein, this material never extends below the interface between the inner and outer segments. Another distinct feature of the deposits at this location was that they contained the predominantly heavier, more toxic, 50- to 64-kDa $\mathrm{A} \beta$ dodecamers, which may be less digestible. Accumulation of these heavier oligomers on outer segments may result in photoreceptor loss and retinal degeneration due to its neurotoxicity. ${ }^{30}$

All three knockout groups showed a significant increase in $\mathrm{A} \beta$ accumulation in both IHC and Western blot data along the RPE/BM interface compared with the C57BL/6 group. However, in each mouse type, the dominant form of $\mathrm{A} \beta$ was the lighter $22-$ to $36-\mathrm{kDa}$ oligomers. Perhaps, this is more digestible by the RPE, but simply accumulates basally because, with age, it is less prone to efficient clearance by the choroidal circulation. In most cases, $A \beta$ deposition on BM was relatively linear. However, in the $\mathrm{CFH}^{-/-} . \mathrm{C}^{-/-}$mice, these focal deposits extend toward the sclera. These are likely to be accumulating on the pillars between the choroidal vessels, because these are focal locations for drusen development in ageing human eyes. ${ }^{46}$ Perhaps the reason is that material expelled from an RPE sitting directly over a blood vessel will be cleared more efficiently than material expelled over a blood vessel pillar. Hence, clearance may be directly related to the proximity of the blood vessels.

Wyss-Coray et $\mathrm{al}^{47}$ showed that complement activation products may be protective against $A \beta$-induced toxicity and may reduce the accumulation or promote the clearance of $A \beta$. It is possible that $C 3$ plays a role in suppressing $A \beta$

\footnotetext{
Figure 6 Retinal macrophages in the subretinal space and levels of inflammation. A: Macrophage numbers positive for Iba- 1 in the subretinal space. All knockout mice have fewer macrophages compared with C57. However, $\mathrm{CFH}^{-1-} . \mathrm{C3}^{-/-}$had fewer than any other groups. On the right is an example of an Iba-1-positive (green) macrophage bloated with $A \beta$ (red) and the nucleus (blue). Sections of each group were immunstained with TNF- $\alpha$ (red) (B and C) and calcitonin (brown staining, $\mathrm{CFH}^{-1-}$ not shown) (D and E). There were no differences between $\mathrm{C} 57$ and $\mathrm{CFH}^{-/-}$mice in both TNF- $\alpha$ and calcitonin expression, but TNF- $\alpha$ levels were significantly elevated in $C 3^{-/-}(P=0.0029)$ and calcitonin was significantly higher in both $C 3^{-/-}$and $\mathrm{CFH}^{-1-} . \mathrm{C3}^{-/-}(P<0.0001$ for both groups $)$. ${ }^{*} P<0.05,{ }^{* *} P<0.005$, and ${ }^{* * * P}<0.0005$. Scale bars: $20 \mu \mathrm{m}(\mathbf{A}) ; 50 \mu \mathrm{m}(\mathbf{B}, \mathbf{D}$, and $\mathbf{E})$. GCL, ganglion cell layer; INL, inner nuclear layer; IPL, inner plexiform layer; $\mathrm{ONL}$, outer nuclear layer; OPL, outer plexiform layer; PR, photoreceptor.
} 
aggregation. ${ }^{47}$ If so, its lack may result in reduced soluble $\mathrm{A} \beta$ in the retina and increased accumulation of insoluble elements along the RPE/BM. $\mathrm{CFH}^{-1-}$ mice also accumulated more $\mathrm{A} \beta$ along their RPE/BM. Wang et $\mathrm{al}^{48}$ showed that $\mathrm{C} 3$-coated exosomes from RPE bind to $\mathrm{CFH}$ and are then stabilized and removed by the circulation. In the absence of $\mathrm{CFH}$, the $\mathrm{C} 3$-coated exosomes, containing extensive cellular debris, including $\mathrm{A} \beta$, become targets for the immunological activity of invading leukocytes. ${ }^{48}$ The absence of $\mathrm{CFH}$ in the complement pathway may cause destabilization of the exosome membrane, release of intracellular proteins into the external environment, and, possibly, incorporation of intracellular proteins, such as $A \beta$, into extracellular debris, leading to an increase in $A \beta$ accumulation along the RPE/BM.

Both $\mathrm{C3}^{-/-}$and $\mathrm{CFH}^{-/-} \cdot \mathrm{C3}^{-/-}$mice have increased photoreceptor cell loss compared with $\mathrm{CFH}^{-/-}$mice, although the latter accumulate almost the same amount of $\mathrm{A} \beta$ as the $C 3^{-/-}$. This suggests that, in the absence of $\mathrm{C} 3$ in $\mathrm{CFH}^{-1-} . \mathrm{C}^{-/-}$and $\mathrm{C}^{-/-}$mice, photoreceptors may be more vulnerable to the cytotoxic effects of $A \beta$, suggesting a role for $\mathrm{C} 3$ in neuronal survival and health. Our results clearly demonstrate that, in the complete absence of $\mathrm{C} 3$ in an AMD murine model, there is an acceleration of the AMD-like pathological features, with an increased accumulation of $\mathrm{A} \beta$ on the RPE/BM and increased photoreceptor loss. The $\mathrm{CFH}^{-/-} . \mathrm{C}^{-/-}$mice showed markedly less $\mathrm{A} \beta$ accumulation along their outer segments, although other material was heavily deposited. This low level of $A \beta$ may indicate that photoreceptor function was impaired because $\mathrm{A} \beta$ was under a normal physiological level. $\mathrm{A} \beta$ not only has a potential pathological role in $\mathrm{AD}$ and $\mathrm{AMD}$, but also in normal central nervous system physiological characteristics. $\mathrm{A} \beta$ activity is required for the essential modulation of synaptic activity and neuronal survival. ${ }^{49,50}$ The proteolytic cleavage of amyloid precursor protein into $A \beta$ is a physiological process; only when net $A \beta$ levels become excessive can this process be regarded as pathological. ${ }^{51}$

All mutant strains have a fivefold decrease in subretinal macrophages. Dailey et al ${ }^{52}$ have shown that the complete depletion of complement proteins leads to reduce macrophage infiltration and activation during peripheral nerve degeneration. This may explain the reduced numbers shown herein and suggest a close relationship between complement components and macrophage recruitment and activation. Microglia/macrophages possess cellular receptors for $\mathrm{C} 3$ fragments through which signaling and macrophage activation may occur in response to free or particle-bound C3 fragments. ${ }^{53}$ Phagocytosis by macrophages/microglia is facilitated by the tagging of pathogens and immune complexes with $\mathrm{C} 3$ fragments for recognition. ${ }^{54}$ In the absence of $\mathrm{C} 3$, macrophages/microglia may not recognize immune complexes or extracellular debris because they are not tagged with C3 fragments and, therefore, the process of phagocytosis may be compromised. Studies ${ }^{55,56}$ have shown that, although monocytes can bind to $\mathrm{C} 3 \mathrm{~b}$ - or
iC3b-carrying particles, they can only progress into macrophages and be activated when bound to factor $\mathrm{H}$. They are then able to phagocytose such particles. This may explain the few activated macrophages in $\mathrm{CFH}^{-/-}$mice.

Inflammation leads to a series of reactions that are harmful to cells, and it is thought that its reduction improves regeneration and functional recovery. ${ }^{57}$ Hence, knocking out $\mathrm{C} 3$ in an AMD mouse model should result in less inflammation because activation of the complement system is compromised. $\mathrm{CFH}^{-1-} . \mathrm{C}^{-/-}$and $\mathrm{C}^{-/-}$mice expressed stronger calcitonin and TNF- $\alpha$, indicative of a chronic proinflammatory state in which cytokines are upregulated. Koenigsknecht-Talboo and Landreth ${ }^{58}$ have shown that chronic inflammation in brains of patients with $\mathrm{AD}$ suppresses activation of phagocytic machinery and affects the ability of microglial cells to mount a phagocytic response, thereby inhibiting normal microglial clearance of $\mathrm{A} \beta$. Consequently, it is possible that proinflammatory cytokines lessened the efficiency of microglial phagocytosis, leading to $A \beta$ accumulation along RPE/BM. Townsend et $\mathrm{al}^{59}$ have shown that, in the presence of proinflammatory cytokines, microglia shift their distinct state from activated to an antigen-presenting phenotype, blocking their ability to phagocytose and increasing production of proinflammatory cytokines. This may explain high expression of TNF- $\alpha$ and reduced macrophages in $\mathrm{C3}^{-/-}$and $\mathrm{CFH}^{-/-} . \mathrm{C}^{-/-}$mice.

Interestingly, it has recently been shown that the absence of C3 receptor for complement activation resulted in a progressive decline in retinal function, hand in hand with the cellular loss. ${ }^{60}$ This reflects our data demonstrating that C3 is critically required for retinal health. The RPE of $\mathrm{C}^{-/-}$mice showed diverse pathological features and regional accumulation of undigested outer segments, suggesting that $\mathrm{C} 3$ is important for RPE integrity and function. There is a significant increase in retinal inflammation in both $\mathrm{C}^{-1-}$ and $\mathrm{CFH}^{-1-} . \mathrm{C}^{-1-}$ mice that have suppressed activation of macrophages, ${ }^{58}$ leading to debris accumulation and resulting in neurodegeneration. Our results indicate a role for $\mathrm{C} 3$ and $\mathrm{CFH}$ in macrophage recruitment and activation. Our initial hypothesis was that $\mathrm{C} 3$ deficiency would protect against retinal pathological features in $\mathrm{CFH}^{-/-}$by preventing inflammation and cellular damage mediated by complement activation. Contrary to expectation, our data are consistent with a major role for $\mathrm{C} 3$ in maintaining retinal health and indicate an additional role for $\mathrm{CFH}$ in this process that is not related to its role in $\mathrm{C} 3$ regulation. The latter point is based on the differences in retinal phenotype between $\mathrm{C3}^{-/-}$and $\mathrm{CFH}^{-1-} . \mathrm{C3}^{-/-}$mice. Because the data were obtained in a model in which $\mathrm{C} 3$ was developmentally, rather than conditionally, depleted, they should be treated cautiously with respect to their implications for C3-inhibiting strategies. However, because there are AMD strategies using complement-targeting therapies in patients, the results obtained herein regarding the role of $\mathrm{C} 3$ need to be considered with care. 


\section{Acknowledgments}

We thank Magella Neveu and Vivian K. Lee for their help with undertaking and interpreting the ERG experiments.

\section{References}

1. Walport MJ: Complement: second of two parts. N Engl J Med 2001, 344:1140-1144

2. Walport MJ: Complement: first of two parts. N Engl J Med 2001, 344:1058-1066

3. Fearon DT: Cellular receptors for fragments of the third component of complement. Immunol Today 1984, 5:105-110

4. Nordahl EA, Rydengard V, Nyberg P, Nitsche DP, Morgelin M, Malmsten M, Bjorck L, Schmidtchen A: Activation of the complement system generates antibacterial peptides. Proc Natl Acad Sci U S A 2004, 101:16879-16884

5. Farries TC, Atkinson JP: Evolution of the complement system. Immunol Today 1991, 12:295-300

6. Erdei A, Fust G, Gergely J: The role of $\mathrm{C} 3$ in the immune response. Immunol Today 1991, 12:332-337

7. Kida M, Fujioka H, Kosaka Y, Hayashi K, Sakiyama Y, Ariga T: The first confirmed case with $\mathrm{C} 3$ deficiency caused by compound heterozygous mutations in the $\mathrm{C} 3$ gene: a new aspect of pathogenesis for C3 deficiency. Blood Cells Mol Dis 2008, 40:410-413

8. Leibowitz HM, Krueger DE, Maunder LR, Milton RC, Kini MM, Kahn HA, Nickerson RJ, Pool J, Colton TL, Ganley JP, Loewenstein JI, Dawber TR: The Framingham Eye Study monograph: an ophthalmological and epidemiological study of cataract, glaucoma, diabetic retinopathy, macular degeneration, and visual acuity in a general population of 2631 adults. 1973-1975. Surv Ophthalmol 1980, 24(Suppl):335-610

9. Klein R, Peto T, Bird A, Vannewkirk MR: The epidemiology of age-related macular degeneration. Am J Ophthalmol 2004, 137 : 486-495

10. Klein R, Klein BE, Jensen SC, Meuer SM: The five-year incidence and progression of age-related maculopathy: the Beaver Dam Eye Study. Ophthalmology 1997, 104:7-21

11. Johnson LV, Leitner WP, Staples MK, Anderson DH: Complement activation and inflammatory processes in Drusen formation and age related macular degeneration. Exp Eye Res 2001, 73:887-896

12. Hageman GS, Luthert PJ, Victor Chong NH, Johnson LV, Anderson DH, Mullins RF: An integrated hypothesis that considers drusen as biomarkers of immune-mediated processes at the RPEBruch's membrane interface in aging and age-related macular degeneration. Prog Retin Eye Res 2001, 20:705-732

13. Anderson DH, Mullins RF, Hageman GS, Johnson LV: A role for local inflammation in the formation of drusen in the aging eye. Am J Ophthalmol 2002, 134:411-431

14. Penfold PL, Madigan MC, Gillies MC, Provis JM: Immunological and aetiological aspects of macular degeneration. Prog Retin Eye Res 2001, 20:385-414

15. Mullins RF, Russell SR, Anderson DH, Hageman GS: Drusen associated with aging and age-related macular degeneration contain proteins common to extracellular deposits associated with atherosclerosis, elastosis, amyloidosis, and dense deposit disease. FASEB J 2000, 14:835-846

16. Anderson DH, Radeke MJ, Gallo NB, Chapin EA, Johnson PT, Curletti CR, Hancox LS, Hu J, Ebright JN, Malek G, Hauser MA, Rickman CB, Bok D, Hageman GS, Johnson LV: The pivotal role of the complement system in aging and age-related macular degeneration: hypothesis re-visited. Prog Retin Eye Res 2010, 29:95-112

17. Klein RJ, Zeiss C, Chew EY, Tsai JY, Sackler RS, Haynes C, Henning AK, SanGiovanni JP, Mane SM, Mayne ST, Bracken MB, Ferris FL, Ott J, Barnstable C, Hoh J: Complement factor $\mathrm{H}$ polymorphism in age-related macular degeneration. Science 2005, 308:385-389

18. Edwards AO, Ritter R 3rd, Abel KJ, Manning A, Panhuysen C, Farrer LA: Complement factor $\mathrm{H}$ polymorphism and age-related macular degeneration. Science 2005, 308:421-424

19. Haines JL, Hauser MA, Schmidt S, Scott WK, Olson LM, Gallins P, Spencer KL, Kwan SY, Noureddine M, Gilbert JR, SchnetzBoutaud N, Agarwal A, Postel EA, Pericak-Vance MA: Complement factor $\mathrm{H}$ variant increases the risk of age-related macular degeneration. Science 2005, 308:419-421

20. Hageman GS, Anderson DH, Johnson LV, Hancox LS, Taiber AJ, Hardisty LI, Hageman JL, Stockman HA, Borchardt JD, Gehrs KM, Smith RJ, Silvestri G, Russell SR, Klaver CC, Barbazetto I, Chang S, Yannuzzi LA, Barile GR, Merriam JC, Smith RT, Olsh AK, Bergeron J, Zernant J, Merriam JE, Gold B, Dean M, Allikmets R: A common haplotype in the complement regulatory gene factor $\mathrm{H}$ (HF1/CFH) predisposes individuals to age-related macular degeneration. Proc Natl Acad Sci U S A 2005, 102:7227-7232

21. Gold B, Merriam JE, Zernant J, Hancox LS, Taiber AJ, Gehrs K, Cramer K, Neel J, Bergeron J, Barile GR, Smith RT, Hageman GS, Dean M, Allikmets R: Variation in factor B (BF) and complement component 2 (C2) genes is associated with age-related macular degeneration. Nat Genet 2006, 38:458-462

22. Yates JR, Sepp T, Matharu BK, Khan JC, Thurlby DA, Shahid H, Clayton DG, Hayward C, Morgan J, Wright AF, Armbrecht AM, Dhillon B, Deary IJ, Redmond E, Bird AC, Moore AT: Complement $\mathrm{C} 3$ variant and the risk of age-related macular degeneration. N Engl J Med 2007, 357:553-561

23. Maller JB, Fagerness JA, Reynolds RC, Neale BM, Daly MJ, Seddon JM: Variation in complement factor 3 is associated with risk of age-related macular degeneration. Nat Genet 2007, 39: $1200-1201$

24. Gehrs KM, Jackson JR, Brown EN, Allikmets R, Hageman GS: Complement, age-related macular degeneration and a vision of the future. Arch Ophthalmol 2010, 128:349-358

25. Mattapallil MJ, Wawrousek EF, Chan CC, Zhao H, Roychoudhury J, Ferguson TA, Caspi RR: The Rd8 mutation of the Crb1 gene is present in vendor lines of C57BL/6N mice and embryonic stem cells, and confounds ocular induced mutant phenotypes. Invest Ophthalmol Vis Sci 2012, 53:2921-2927

26. Lundh von Leithner P, Kam JH, Bainbridge J, Catchpole I, Gough G, Coffey P: Jeffery G: Complement factor $\mathrm{h}$ is critical in the maintenance of retinal perfusion. Am J Pathol 2009, 175:412-421

27. Al-Hussaini H, Kam JH, Vugler A, Semo M, Jeffery G: Mature retinal pigment epithelium cells are retained in the cell cycle and proliferate in vivo. Mol Vis 2008, 14:1784-1791

28. Del Priore LV, Kuo YH, Tezel TH: Age-related changes in human RPE cell density and apoptosis proportion in situ. Invest Ophthalmol Vis Sci 2002, 43:3312-3318

29. Hoh Kam J, Lenassi E, Jeffery G: Viewing ageing eyes: diverse sites of amyloid Beta accumulation in the ageing mouse retina and the upregulation of macrophages. PLoS One 2010, 5. pii: e13127

30. Lesne S, Koh MT, Kotilinek L, Kayed R, Glabe CG, Yang A, Gallagher M, Ashe KH: A specific amyloid-beta protein assembly in the brain impairs memory. Nature 2006, 440:352-357

31. Brouckaert P, Libert C, Everaerdt B, Takahashi N, Cauwels A, Fiers W: Tumor necrosis factor, its receptors and the connection with interleukin 1 and interleukin 6. Immunobiology 1993, 187: 317-329

32. Bian ZM, Elner SG, Strieter RM, Kunkel SL, Lukacs NW, Elner VM: IL-4 potentiates IL-1 beta- and TNF-alpha-stimulated IL-8 and MCP-1 protein production in human retinal pigment epithelial cells. Curr Eye Res 1999, 18:349-357

33. Elner SG, Strieter RM, Elner VM, Rollins BJ, Del Monte MA, Kunkel SL: Monocyte chemotactic protein gene expression by cytokine-treated human retinal pigment epithelial cells. Lab Invest 1991, 64:819-825 
34. Chen M, Muckersie E, Forrester JV, Xu H: Immune activation in retinal aging: a gene expression study. Invest Ophthalmol Vis Sci 2010, 51:5888-5896

35. Rougier N, Kazatchkine MD, Rougier JP, Fremeaux-Bacchi V, Blouin J, Deschenes G, Soto B, Baudouin V, Pautard B, Proesmans W, Weiss E, Weiss L: Human complement factor H deficiency associated with hemolytic uremic syndrome. J Am Soc Nephrol 1998, 9: 2318-2326

36. Levy M, Halbwachs-Mecarelli L, Gubler MC, Kohout G, Bensenouci A, Niaudet P, Hauptmann G, Lesavre P: H deficiency in two brothers with atypical dense intramembranous deposit disease. Kidney Int 1986, 30:949-956

37. Hogasen K, Jansen JH, Mollnes TE, Hovdenes J, Harboe M: Hereditary porcine membranoproliferative glomerulonephritis type II is caused by factor $\mathrm{H}$ deficiency. J Clin Invest 1995, 95:1054-1061

38. Pickering MC, Cook HT, Warren J, Bygrave AE, Moss J, Walport MJ, Botto M: Uncontrolled C3 activation causes membranoproliferative glomerulonephritis in mice deficient in complement factor H. Nat Genet 2002, 31:424-428

39. Coffey PJ, Gias C, McDermott CJ, Lundh P, Pickering MC, Sethi C, Bird A, Fitzke FW, Maass A, Chen LL, Holder GE, Luthert PJ, Salt TE, Moss SE, Greenwood J: Complement factor $\mathrm{H}$ deficiency in aged mice causes retinal abnormalities and visual dysfunction. Proc Natl Acad Sci U S A 2007, 104:16651-16656

40. Booij JC, Baas DC, Beisekeeva J, Gorgels TG, Bergen AA: The dynamic nature of Bruch's membrane. Prog Retin Eye Res 2010, 29:1-18

41. Graymore CN, Kissun RD: Use of phenazine methosulphate (PMS) in the histochemical localization of lactic acid dehydrogenase (LDH) in the retina. Exp Eye Res 1969, 8:375-378

42. Medrano CJ, Fox DA: Oxygen consumption in the rat outer and inner retina: light- and pharmacologically-induced inhibition. Exp Eye Res 1995, 61:273-284

43. Arden GB, Hamilton AM, Wilson-Holt J, Ryan S, Yudkin JS, Kurtz A: Pattern electroretinograms become abnormal when background diabetic retinopathy deteriorates to a preproliferative stage: possible use as a screening test. Br J Ophthalmol 1986, 70:330-335

44. Usami E: [Studies on the method of measurement of the oscillatory potential in ERG]. Japanese. Nihon Ganka Gakkai Zasshi 1966, 70: 84-87

45. Usami E: Studies on ERG of occlusion of the retinal artery and vein especially on that prognostic value, [in Japanese]. Nihon Ganka Gakkai Zasshi 1967, 71:39-45

46. Lengyel I, Tufail A, Hosaini HA, Luthert P, Bird AC, Jeffery G: Association of drusen deposition with choroidal intercapillary pillars in the aging human eye. Invest Ophthalmol Vis Sci 2004, 45:2886-2892

47. Wyss-Coray T, Yan F, Lin AH, Lambris JD, Alexander JJ, Quigg RJ, Masliah E: Prominent neurodegeneration and increased plaque formation in complement-inhibited Alzheimer's mice. Proc Natl Acad Sci U S A 2002, 99:10837-10842

48. Wang AL, Lukas TJ, Yuan M, Du N, Tso MO, Neufeld AH: Autophagy and exosomes in the aged retinal pigment epithelium: possible relevance to drusen formation and age-related macular degeneration. PLoS One 2009, 4:e4160

49. Tamaoka A, Sawamura N, Fukushima T, Shoji S, Matsubara E, Shoji M, Hirai S, Furiya Y, Endoh R, Mori H: Amyloid beta protein 42(43) in cerebrospinal fluid of patients with Alzheimer's disease. J Neurol Sci 1997, 148:41-45

50. Haass C, Schlossmacher MG, Hung AY, Vigo-Pelfrey C, Mellon A, Ostaszewski BL, Lieberburg I, Koo EH, Schenk D, Teplow DB, Selkow DJ: Amyloid $\beta$-peptide is produced by cultured cells during normal metabolism. Nature 1992, 359:322-325

51. Puzzo D, Privitera L, Palmeri A: Hormetic effect of amyloid-beta peptide in synaptic plasticity and memory. Neurobiol Aging 2012, 33:1484.e15-1484.e24

52. Dailey AT, Avellino AM, Benthem L, Silver J, Kliot M: Complement depletion reduces macrophage infiltration and activation during Wallerian degeneration and axonal regeneration. J Neurosci 1998, 18 : 6713-6722

53. Fearon DT, Wong WW: Complement ligand-receptor interactions that mediate biological responses. Annu Rev Immunol 1983, 1: 243-271

54. Stuart LM, Ezekowitz RA: Phagocytosis: elegant complexity. Immunity 2005, 22:539-550

55. Hartung HP, Hadding U, Bitter-Suermann D, Gemsa D: Release of prostaglandin $\mathrm{E}$ and thromboxane from macrophages by stimulation with factor H. Clin Exp Immunol 1984, 56:453-458

56. Dierich MP, Erdei A, Huemer H, Petzer A, Stauder R, Schulz TF, Gergely J: Involvement of complement in B-cell, T-cell and monocyte/macrophage activation. Immunol Lett 1987 , $14: 235-242$

57. Brambilla R, Bracchi-Ricard V, Hu WH, Frydel B, Bramwell A, Karmally S, Green EJ, Bethea JR: Inhibition of astroglial nuclear factor kappaB reduces inflammation and improves functional recovery after spinal cord injury. J Exp Med 2005, 202:145-156

58. Koenigsknecht-Talboo J, Landreth GE: Microglial phagocytosis induced by fibrillar beta-amyloid and IgGs are differentially regulated by proinflammatory cytokines. J Neurosci 2005, 25:8240-8249

59. Townsend KP, Town T, Mori T, Lue LF, Shytle D, Sanberg PR, Morgan D, Fernandez F, Flavell RA, Tan J: CD40 signaling regulates innate and adaptive activation of microglia in response to amyloid beta-peptide. Eur J Immunol 2005, 35:901-910

60. Yu M, Zou W, Peachey NS, McIntyre TM, Liu J: A novel role of complement in retinal degeneration. Invest Ophthalmol Vis Sci 2012, 53:7684-7692 